space allotted to details of the technique and application of the slitlamp, diathermy, and electro-magnet are justified in a work of this scope. A chapter on diseases of the eye follows in which the several structures are considered in the usual manner, though so briefly as to offer only a bare introduction to the subject. The rest of the book consists of a miscellaneous collection of observations on night vision, preventive ophthalmology, simple and gas burns of the eye, sympathetic ophthalmia, and ophthalmology on active service, all of particular interest and value to the serving officer. In this connection it is suprising that fractures of the orbit, so often seen in war casualties and so readily overlooked, receive scant attention.

This york does not deal with ophthalmological problems from the point of view of the established specialist, nor can it be said to offer sufficient basic instruction for the newcomer. Its chief value would seem to be for the ophthalmic surgeon, be he junior or senior, who is about to embark on an Army career, for within these pages will be found a number of useful hints and suggestions from one widely experienced in service ophthalmology.

\title{
CORRESPONDENCE
}

\section{FACULTY OF OPHTHALMOLOGY}

\section{To the Editors of THE BRITISH JOURNAL OF OPHTHALMOLOGY.}

SIR,-Negotiations which have been proceeding for the past twelve months between the Association of British Ophthalmologists and the Council of British Ophthalmologists for the purpose of fusing together and founding a single Joint Body representing all ophthalmologists in the ophthalmo-political sphere, have finally broken down.

The reasons which underlie this failure are fraught with implications so derogatory to the future welfare of the ophthalmic medical profession and the service it provides for the public as to render.it imperative that they be brought to the notice of the profession as a whole in the hope that the publicity may provide the corrective which reason and private discussion have so signally failed to achieve.

It should be explained in the first place that the A.B.O. is an actively functioning, democratically constituted, ophthalmo-political Body which represents approximately half the number of full-time practising ophthalmologists in the country and which is also open 
to part-time ophthalmic practitioners of experience. The C.B.O. has quite a different constitution, being composed of some 15/20 senior ophthalmic surgeons mainly in the London area. It is virtually self-elected, and its function in the past has been confined to matters of ophthalmic interest arising in connection with national industries and public services, (e.g. working out visual standards, etc.). It has had a purely nominal existence unknown to the mass of ophthalmologists, and has been almost moribund for the past decade at least. The average age of its members must be between $60 / 65$, all in an assured position, and they held aloof from any interest in current ophthalmo-political matters until the A.B.O. passed a Motion at the Annual General Meeting in - 1943 to initiate a movement to found a College or Faculty or similar Institute of Ophthalmology.

It would seem that they were then suddenly stimulated into a very active interest. The Council of the A.B.O. welcomed this in the hope that its origin was disinterested but it transpires that their intention was, and remains, to take control of the movement and direct its future course and, in effect, to thoroughly sabotage and delay by hook or by crook a sound and constructive professional development which is deemed long overdue by the vast majority of ophthalmologists.

The facts speak for themselves.

Three Joint Sub-Committee Meetings were held with the object of dissolving the existing organisations and forming a Joint Body to which every man in the country would belong. The first rift was the insistence of the C.B.O. to designate one of its representatives to act as the Chairman of the Joint Sub-Committee and thereafter to confine discussion to a Memorandum it had prepared. Good will and good sense overcame this difficulty. It then transpired that the C.B.O. desired the new Body to assume the title of a Faculty, but it insisted that this Faculty should be unique amongst all other medical Faculties by the exclusion of Fellows. Members and Associate Members were to be permitted. Members alone were to be allowed voting powers. A non-elected senior directorate or "Upper House" was also indicated as being necessary. It was also indicated that the constitution of the Faculty was not to be subject to alteration by any future majority vote of the constituent members.

The Council of the A.B.O. unanimously upheld the decision of its representatives to turn down these one-sided and reactionary proposals. It directed that negotiations must proceed on the following completely democratic lines, viz :-

1. It would accept the title Faculty for the new Joint Body but suggested that the separate academic and political functions would 
best be subserved by separately elected Councils for each function. Later it gave way on this point.

2. It would accept the title Faculty only if it were to be composed of. Fellows, Members, and Associate Members. It finally gave way on this in the interests of professional unity (and with the dissent of many of its Councillors) and accepted the exclusion of Fellows.

3. It insisted that the constitution of the proposed Faculty must be entirely democratic, and that election to the Council of the proposed Faculty must be by vote, and that a majority postal vote of Members must be binding on all matters, and that the proposed Constitution must be subject to alteration annually in the same democratic fashion. It has refused to give way on this point, hence the final failure of negotiations.

An.interesting reflection on the mentality which the C.B.O. has shown during these negotiations has been the insistence on depriving consultant ophthalmologists of the right to collectively organise and direct their own affairs, by means of the transparent devices to which I have very briefly directed attention. They quite openly state that they fear " mob rule?" within the profession and that a non-elected "Upper House" or "Senate" with authoritarian powers is imperative. There are some five hundred full-time eye men in the country, and should the development of events prove that they are amenable to the set-up the C.B.O. is so ingeniously preparing for them, it will also prove that the C.B.O. assessment of their intellectual level is not wholly unwarranted, however insulting !

Quite a number of ophthalmologists who have been negotiating for the C.B.O. have indicated that they support the principles insisted upon by the A.13.O. but despite this they seem determined to support the new Faculty. The Faculty has been registered by the C.B.O. already, and this step was taken during an interval between negotiations without the knowledge or approval of the A.B.O., and at a time when the A.B.O, had been requested not to take any official steps which might in any way upset the mutually desired successful conclusion of the negotiations! Medical ethics

- have, reached a sorry pass indeed if a responsible group can so "stoop to conquer."

Such being the state of the matter at present, it remains only to indicate that a small group of consultants are prepared to go to any lengths to secure and maintain control of the profession, and as it is crystal clear that this is not in the interest of the profession as a whole, one is left with the assumption that it must be in the interest of this small group. They appear to possess the support of the 
Royal College of Surgeons, but it is doubtful if this will be continued when the latter are acquainted with all the revelant facts.

I acted as President of the A.B.O. immediately prior to the commencement of the negotiations referred to and can vouch for the facts I have given. I feel strongly that all such attempts to foist quasi-Corporative Bodies on the profession should be given short shrift, and that the best method is to expose them to the criticism of one's colleagues.

Yours faithfully,

LIONEL M. GREEN.

To the Editors of THE BRITISH JouRnal OF OPHTHalmology.

SiR,-It is impossible to reply within reasonable timits to all the misleading, and often quite inaccurate statements in Mr. Green's letter.

His allegations with regard to the constitution and activities of The Council of British Ophthalmologists seem to show that he has never troubled to learn how it is constituted nor to acquaint himself with its work. I cannot otherwise account for his extraordinary assertion that it is virtually self-elected. Surely he cannot believe that the Presidents of The Ophthalmological Society of the United Kingdom and of The Section of Ophthalmology of the Royal Society of Medicine and the Master of the Oxford Congress are self-elected; yet it is as holders of those offices that they have become members of the C.B.O. The other members elected annually by the councils of these three bodies, and the one in recent years nominated by the A.B.O., can by no stretch of imagination be described as self-elected. His statement that the C.B.O. has had a purely nominal existence, unknown to the mass of ophthalmologists, implies that the persons constituting the "mass of ophthalmologists" are neither members of the Ophthalmological Society of the United Kingdom nor readers of the British Journal of Ophthalmology. The O.S.U.K. is universally recognised as the leading scientific ophthalmological organisation in the country. It has between 500 and 600 members, and every member has received each year, with the final notice of the Annual Congress, notice of a general meeting open to all ophthalmologists to receive and discuss the annual report of the C.B.O.

These open meetings have been held every year since 19.19 except during two early years of the present war. Mr. Green appears to have been unaware of these meetings, which were held at the time of the Annual Congress of the O.S.U.K. to suit the convenience of 
the large numbers of ophthalmologists from all parts of the Kingdom attending it.

The annual reports and very many special reports have been published in the British Journal of Ophthalmology. If Mr. Green had heard or read these reports he would have learned that the activities of the C.B.O. have been by no means as restricted as he suggests, and that they have comprised work in the political field of very considerable importance, especially in relation to "optical" benefit under National Health Insurance and in connection with the efforts of sight-testing opticians to abtain statutory recognition.

$\mathrm{He}$ is totally mistaken in supposing that the proposal for the foundation of a Faculty was in any way influenced by the passing of a resolution by the Council of the A.B.O., an event of which the great majority of members of the C.B.O. certainly had no knowledge.

Some members of the C.B.O. have long felt that its position would be strengthened if it were reconstituted on a wider and more directly representative basis, and proposals for reform of its constitution were under consideration as early a's the summer of 1942.

In March 1943, a memorandum on the subject was presented by one of its members, and a committee was then appointed to consider the question. I was appointed chairman of that committee, which was given power to co-opt any persons whose collaboration it thought would be useful. After preliminary discussions the committee decided that an attempt should be made to draw up a plan for a single comprehensive body representative of all ophthalmologists in the country, and therefore invitéd the A.B.O. to co-operate by nominating representatives to attend the meetings of the committee. The Ophthalmic Group Committee of the B.M.A. was also approached, and was represented at meetings of the committee by its Chairman. The question of any change in the chairmanship of the committee was never raised, and I entirely fail to understand Mr. Green's reference to a rift on that point.

The original draft plan submitted to the cominittee as a basis for discussion was very similar to that eventually adopted by the C.B.O. and published in your last issue. There was never any suggestion that Associates should have no voting powers, nor was it ever proposed that there should be "a non-elected senior directorate or Upper House."

Although a considerable measure of agreement was reached on many points negotiations finally broke down because it became apparent that the A.B.O. would not accept a plan ensuring that a majority of the members of the Council of the Faculty should be elected by persons of real consultant status, a condition which the C.B.O. considered of vital importance. The plan for the formation of a Faculty of Ophthalmologists sponsored by the C.B.O. has now 
been published, and readers can form their own opinions with regard to many of the charges contained in Mr. Green's letter. One further point, however, calls for a definite answer-his protest concerning the registration of the Faculty "during an interval between negotiations." This action was taken by the C.B.O. at a time when negotiations appeared finally to have broken down and after an overt threat by a representative of the A.B.O. that we should find there would be legal obstacles to the establishment of the Faculty.-

Mr. Green does not state whether he is expressing the considered opinions of the Council and Members of the A.B.O. or writing as an individual, I hope the latter, as I feel there must be many members of the A.B.O. who will be willing to co-operate in the establishment of the Faculty as a comprehensive body fully representative of all British ophthalmologists.

Yours faithfulfy,

W. H. MCMULLEN.

Chairman of Organising Committee of Faculty of Ophthalmologists.

\section{PLASTIC SPHERES}

To the Editors of The British Journal of Ophthalmology.

DEAR SiRs,-The article on plastic spheres by Major R. E. Wright, C.I.E., in the Brit. Jl. of Ophthal., November, 1944, will be read with considerable interest by ophthalmologists of the Central Mediterranean Forces.

- Perspex globes of $12-16 \mathrm{~mm}$. have been used by them for Tenon implantation for some months and are now an issue. At first, an R.A.F. Maintenance Unit kindly made them from scrap turret ribs, but now they are manufactured by the ever co-operative R.E.M.E.

So far as I am aware, 'no undue tissue reactions have occurred and excellent cosmetic results have been seen. Movement up, in, and down is generally good, but limited outwards.

We can thoroughly endorse the points of technique which Major Wright stresses. namely, a neat flat suture line and a reform prosthesis.

It is also found that an implant socket heals more readily than one following an ordinary enucleation, and that an artificial eye is well tolerated a fortnight after operation; this is of importance in military practice.

Delayed implants into recent clean sockets have been made with good results. 